\title{
POSSIBLE ANALGESIC EFFECT OF VIGABATRIN IN ANIMAL EXPERIMENTAL CHRONIC NEUROPATHIC PAIN
}

\author{
NILZA D. ALVES* CARLOS M. DE CASTRO-COSTA**, ALBA M. DE CARVALHO***, \\ FRANKLIN J. C. SANTOS***, DELANO G. SILVEIRA***
}

\begin{abstract}
Since anticonvulsants have been used for treating neuralgias, an interest has arisen to experimentally test vigabatrin for its gabaergic mechanism of action. For this, 41 Wistar rats were used, and in 25 of them a constrictive sciatic neuropathy was induced (Bennet \& Xie model). For testing pain symptoms, spontaneous (scratching) and evoked behaviors to noxious $\left(46^{\circ} \mathrm{C}\right)$ and non-noxious $\left(40^{\circ} \mathrm{C}\right)$ thermal stimuli were quantified. Moreover, a comparative pharmacological study of vigabatrin with other analgesic anticonvulsant drugs was also performed. The results showed a possible dose-dependent analgesic effect of vigabatrin (gamma-vinylGABA) on experimental neuropathic pain, as shown by the significant $(\mathrm{p}<0.05)$ decreasing effect of vigabatrin on scratching and by its significant $(\mathrm{p}<0.05)$ increasing effect on the latency of the right hindpaw withdrawal of the animals to noxious thermal stimulus. This was corroborated by similar findings with analgesic anticonvulsants (carbamazepine, phenytoin and valproic acid). This possible and not yet described analgesic effect of vigabatrin seems not to be opioid mediated.
\end{abstract}

KEY WORDS: vigabatrin, experimental, neuropathic pain, scratching behavior, thermal tests, Wistar rats, analgesia.

\section{Possível efeito analgésico da vigabatrina na dor neuropática crônica experimental animal}

RESUMO - O uso de anticonvulsivantes no tratamento de neuralgias despertou um interesse em testar novas drogas anticonvulsivantes, e dentre essas a vigabatrina por possuir mecanismo de ação gabaérgico. Para isso, foram usados 41 ratos Wistar e em 25 deles induziu-se neuropatia ciática constritiva (modelo de Bennett \& Xie). Para testar sintomas de dor, foram quantificados comportamentos espontâneos (coçar-se) e evocados, por meio de estímulos térmicos nocivos $\left(46^{\circ} \mathrm{C}\right)$ e não-nocivos $\left(40^{\circ} \mathrm{C}\right)$. Além disso, realizou-se estudo comparativo da vigabatrina com outros anticonvulsivantes analgésicos. Os resultados mostraram um possível efeito analgésico, dose-dependente, de vigabatrina (gama-vinil-GABA) em dor neuropática experimental. Isso foi evidenciado pela diminuição significativa $(\mathrm{p}<0,05)$ do comportamento de coçar-se e pelo aumento significativo $(\mathrm{p}<0,05)$ da latência de retirada da pata posterior direita a estímulos térmicos nocivos. Isso foi corroborado por achados semelhantes em experimentos com anticonvulsivantes (carbamazepina, fenitoína e ácido valpróico) analgésicos. Esse possível efeito analgésico da vigabatrina (ainda não descrito na literatura) não é mediado pelo sistema opióide.

PALAVRAS-CHAVE: vigabatrina, experimental, dor neuropática, comportamento de coçar-se, testes térmicos, ratos Wistar, analgesia.

The treatment of chronic neuropathic pain is varied and only partially effective ${ }^{1}$. Davies et al. ${ }^{2}$ have reported on the use of anticonvulsant and antidepressive drugs in the treatment of chronic neuropathic pain. The anticonvulsant drugs are able of reverting or avoiding seizures. These drugs act by decreasing the neuronal response to seizures-inducing stimuli. Since it is known that in neuropathic pain abnormal electrical activity exists in neurons and nerve fibers, anticonvulsant drugs have a role in its treatment, because neuropathic pain seems to have common physiopathogenic mechanisms with seizures. In this way, phenytoin and carbamazepine have been evidenced to exert

Laboratory of Experimental Neurology (Department of Physiology and Pharmacology), Federal University of Ceará (UFC), Brazil: *MD, MsC; **MD, MsC, PhD; ***MD. Aceite: 14-agosto-1999.

Dra. Nilza Dutra Alves - Laboratório de Neurologia Experimental e Neurofisiologia - Departamento de Fisiologia e Farmacologia/UFC - Rua Cel. Nunes de Melo 1127 - 60430-270 Fortaleza CE - Brasil. Fax: 55852439333. 
analgesic effect on trigeminal neuralgia, glossopharyngeal and occipital nerve neuralgia $\mathrm{a}^{3,4}$ and diabetic neuropathy ${ }^{5}$. Moreover, Moura ${ }^{6}$ has shown results that suggest an analgesic effect of carbamazepine on experimental constrictive sciatic mononeuropathy. With the introduction of new anticonvulsants, such as gabapentin ${ }^{7,8}$, lamotrigin ${ }^{9,10}$ and vigabatrin (gamma-vinyl-GABA) ${ }^{11}$, a gabaergic drug, a renewed interest has arisen for their use in neuropathic pain.

The absence of reference in the literature on the effect of vigabatrin in chronic neuropathic pain lead us to test it in an animal model of chronic neuropathic pain, as described by Bennett and $\mathrm{Xie}^{12}$ and modified by Seltzer et al. ${ }^{13}$.

Our paper aims at defining the analgesic effect of vigabatrin in experimental chronic neuropathic pain and compare it with the effect of other analgesic anticonvulsants (carbamazepine, phenytoin and valproic acid), and to distinguish the eventual opioid participation in the possible analgesic effect of vigabatrin.

\section{METHOD}

Forty-one Wistar rats were used for the experiments. They were subdivided into four groups, with two control groups of eight animals in each one. These control groups were formed by eight normal and eight shamoperated animals. For the experimental group, 25 rats were used. All animals weighted between 180 and $330 \mathrm{~g}$, and were aged of 7 months in the beginning of the experiments.

For reproduction of the neuropathic model, the method of Bennet and Xie ${ }^{12}$ modified by Seltzer et al. ${ }^{13}$ has been followed: the rats were anesthetized with hypnorm (fluanisonum $10 \mathrm{mg}+$ fentanylum $0.2 \mathrm{mg} / \mathrm{ml}$ ) in a dosage of $1 \mathrm{ml} / 100 \mathrm{~g}$ of body weight, injected in the hindlimb, intramuscularly. After transecting the fascia between the gluteus and biceps femoris nerve, the right common sciatic nerve was exposed at the level of the midthigh, proximal to its trifurcation, and the nerve was carefully dissected from its surrounding tissue over a distance of about $8 \mathrm{~mm}$. In the experimental group, four ligatures were loosely tied around the common sciatic nerve with sterile noninflammatory mononylon 4.0 thread. This latter procedure differed somewhat from the original description. As a control, the left sciatic nerve was similarly exposed, but not ligated or touched. This procedure was also done for the sham-operated animals, where the sciatic nerve was similarly exposed, but not ligated, on both sides.

The observations of the spontaneous (stress-free) behaviors were performed as previously described by De Castro-Costa et al. ${ }^{14}$ and Kupers et al. ${ }^{15}$. The rats were then placed in a faintly illuminated observation cage $(100 \times 50 \times 50 \mathrm{~cm})$ with the floor covered with wood shavings. The cage was placed in a darkened and silent room. The front of the cage was made of glass, which permitted the experimenter to observe the behavioral elements of the animal. After an adaptation period of five minutes, the observations started. During a period of 30 minutes, the behavior of the rat was systematically recorded by immediately pressing one of the keys of a keyboard, corresponding to the various elements of the rat's behavior. The keyboard was connected to a computer, which stored the data. The following behaviors were recorded: freezing, rearing, sniffing, grooming, eating, rest/sleeping and scratching with right or left hindpaw towards the head, flank or the air. The observations were carried out during four consecutive days, and after, every $7^{\text {th }}$ day, during 12 weeks. Moreover, the animals were also submitted to thermal tests. These tests, as described by Attal et al. ${ }^{16}$, consisted of immersing the hindlimbs of the rats into water heated from $40^{\circ} \mathrm{C}$ to $46^{\circ} \mathrm{C}$. The rat was carefully manipulated by the experimenter and wrapped in a towel so that its extended hindpaws and head were free. Each extended hindpaw was then immersed, and the struggle and paw flick latency reaction of the animal was observed and recorded by the use of a chronometer. A cut-off period of $15 \mathrm{sec}$. was established for these tests, and we selected $40^{\circ} \mathrm{C}$ for non-noxious and $46^{\circ} \mathrm{C}$ for noxious stimuli.

The pharmacological tests aimed at testing the analgesic effect of vigabatrin in chronic neuropathic pain and at comparing it with that of valproic acid, phenytoin and carbamazepine. The vigabatrin (gamma-vinylGABA) is an inhibitor of GABA-amino-transferase, developed by Marion Merrell Dow and marketed as Sabril by Merrell Lepetit Pharmaceutical Industry.

Vigabatrin, in doses of $1,5,10$ and $20 \mathrm{mg} / \mathrm{kg}$, per os, and in a dilution of $1 \mathrm{ml} / 100 \mathrm{~g}$ of body weight in distilled water, was tested in 10 neuropathic rats. The observations began $90 \mathrm{~min}$. after the administration of each dosis of the drug. The thermal tests were carried out $120 \mathrm{~min}$. after the administration of each dosis. For the administration of each dosis, an interval of 72 hours of pharmacological rest was respected.

To test an eventual opioid participation in the vigabatrin analgesic effect, naloxone was also tested. For this, vigabatrin, in a dosis of $20 \mathrm{mg} / \mathrm{kg}$, per os, and naloxone, in an intraperitoneal dosis of $2.5 \mathrm{mg} / \mathrm{kg}$, were used, and the same time intervals were kept after the drug administration. 
Valproic acid was administered, per os, in a dosis of $15 \mathrm{mg} / \mathrm{kg}$, with the same time intervals as for vigabatrin.

Carbamazepine, in a dosis of $10 \mathrm{mg} / \mathrm{kg}$, per os, was used. The observations began $15 \mathrm{~min}$ after the drug administration and the thermal tests after $45 \mathrm{~min}$.

Phenytoin was administered in a dosis of $5 \mathrm{mg} / \mathrm{kg}$, per os, and the behavioral observations began $60 \mathrm{~min}$. after the administration and the thermal tests after $90 \mathrm{~min}$.

The ethical guidelines from IASP have been followed ${ }^{17}$ : the number of animals was kept to a minimum and the duration of the experiments was as short as possible.

For the statistical analysis of the results, a computer Sigma Stat ${ }^{\circledR}$ program was used, with the following tests: ANOVA, for testing the population normality; Dunn's or De Bonferroni's tests, for non-normal population; and Kruskal-Wallis and the Student-Newman-Keuls or Dunn's tests, for comparison of groups. Results were considered significant when $\mathrm{p}$ values were lower than 0.05 .

\section{RESULTS}

From the 25 experimental animals, 20 developed constrictive sciatic mononeuropathy, as evidenced by a significant $(\mathrm{p}<0.05$ ) increase of the scratching behavior in the right hindpaw (Fig. 1) and by the results of the thermal tests. These results have shown the presence of allodynia in the neuropathic animals for their decreased response to the thermal stimulus at $40^{\circ} \mathrm{C}$. As to the thermal noxious stimulus of $46^{\circ} \mathrm{C}$, the response of the right hindpaw of the neuropathic animals was similar to that of the control rats.

Vigabatrin decreased significantly $(\mathrm{p}<0.05)$, in a dose-dependent way, the scratching behavior in the right hindpaw (Fig. 2) of the neuropathic rats. In the same sense, vigabatrin induced, in the same animals, a significant $(\mathrm{p}<0.05)$ increase of the latency of the right hindpaw withdrawal to the non-noxious stimulus of $40^{\circ} \mathrm{C}$ in the doses of 10 and $20 \mathrm{mg} / \mathrm{kg}$ (Fig. 3), reverting this way the allodynia. As to the noxious thermal stimulus of $46^{\circ} \mathrm{C}$, there was a significant $(\mathrm{p}<0.05)$ increase of the latency of the right hindpaw withdrawal in the doses of 5, 19 and $20 \mathrm{mg} / \mathrm{kg}$ (Fig. 4), what suggests a dose-dependent analgesic effect in the neuropathic rats.

Valproic acid, carbamazepine and phenytoin also decreased significantly $(\mathrm{p}<0.05)$ the scratching behavior in the right hindpaw of neuropathic rats. These drugs, equally, increased

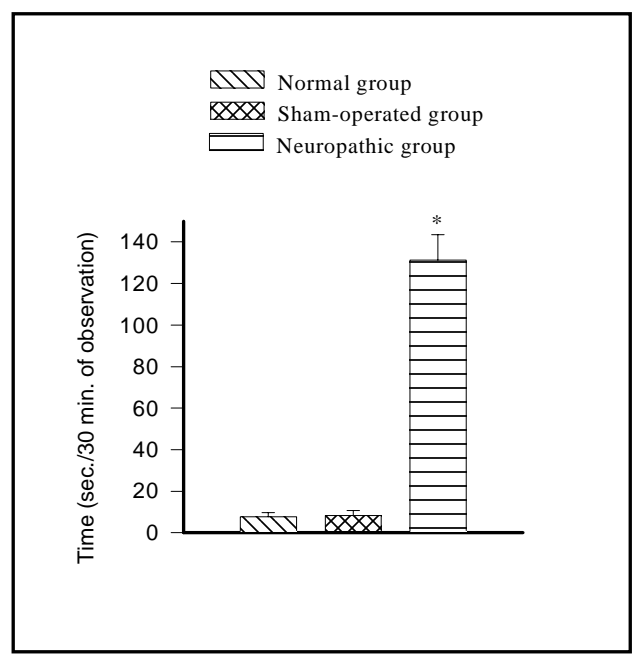

Fig. 1: Time of scratching behavior in the right hindpaw in normal $(n=8)$, sham-operated $(n=8)$ and neuropathic $(n=10)$ animals. The values are expressed in mean \pm S.E.M. *Represents the statistical significance among the groups, Dunn's test $(p<0.05)$, related to values obtained in the control groups.

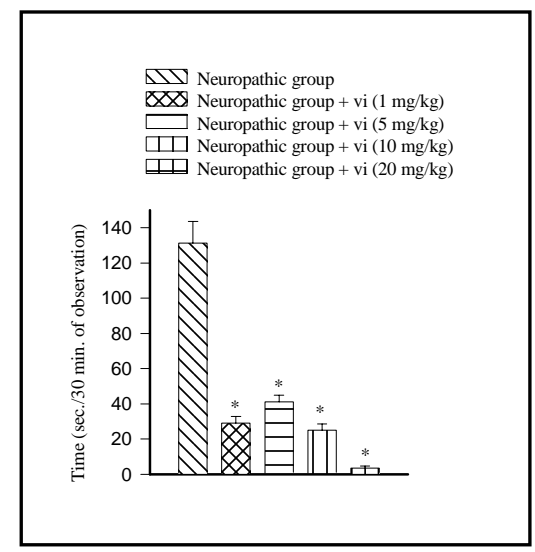

Fig. 2: Time of scratching behavior in the neuropathic rats with saline (experimental control group, $n=10$ ) in comparison with the neuropathic rats with vigabatrin in the different doses of 1, 5, 10 and $20 \mathrm{mg} / \mathrm{kg}(\mathrm{n}=10)$. The values are expressed in mean \pm S.E.M.

* Represents the statistical significance among the groups, Student-Newman-Keuls test ( $p<0.05$ ), related to values obtained in the control groups. 


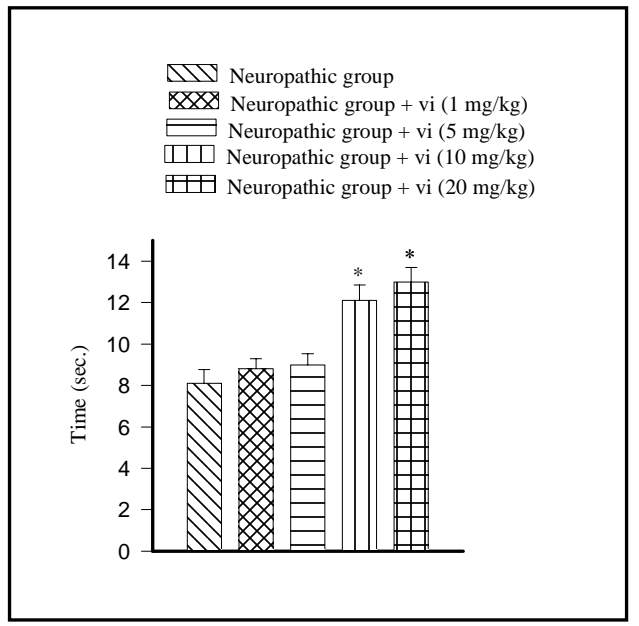

Fig. 3. Thermal test (latency of the right hindpaw withdrawal) in the neuropathic rats with saline (experimental control group, $n=10$ ) in comparison with the neuropathic rats with vigabatrin in the different doses of $1,5,10$ and $20 \mathrm{mg} / \mathrm{kg}(\mathrm{n}=10)$ in a temperature of $40^{\circ} \mathrm{C}$.

The values are expressed in mean \pm S.E.M.

* Represents the statistical significance among the groups, Student-Newman-Keuls test $(p<0.05)$, related to values obtained in the control groups.

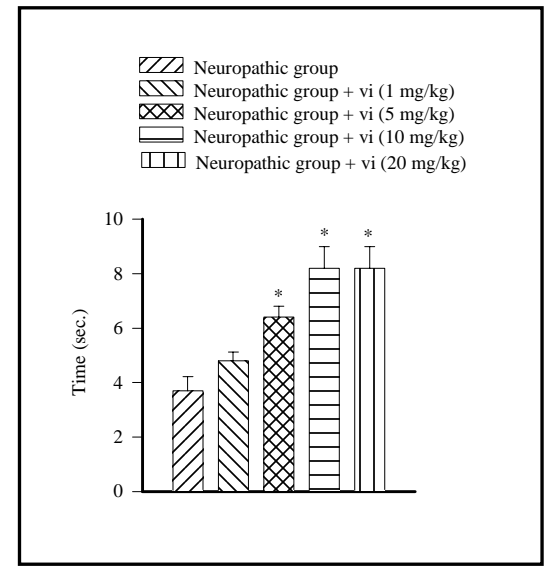

Fig. 4. Thermal test (latency of the right hindpaw withdrawal) in the neuropathic rats with saline (experimental control group, $n=10$ ) in comparison with the neuropathic rats with vigabatrin in the different doses of $1,5,10$ and $20 \mathrm{mg} / \mathrm{kg}$ $(n=10)$ in a temperature of $46^{\circ} \mathrm{C}$. The values are expressed in mean \pm S.E.M.

* Represents the statistical significance among the groups, Student-Newman-Keuls test ( $p<0.05$ ), related to values obtained in the control groups.

significantly $(\mathrm{p}<0.05)$ the latency of the right hindpaw withdrawal to non-noxious $\left(40^{\circ} \mathrm{C}\right)$ and noxious $\left(46^{\circ} \mathrm{C}\right)$ thermal stimuli in those animals.

Naloxone did not revert the vigabatrin effect on the scratching behavior and on the latency of the right hindpaw withdrawal to thermal stimuli in the neuropathic animals.

\section{DISCUSSION}

Vigabatrin (gamma-vinyl-GABA) has been used as an anticonvulsant in the treatment of refractory partial epilepsy, and this has been shown in epileptic patients with the use of placebo ${ }^{18}$ and of another anticonvulsant ${ }^{19}$. This drug is shown to suppress stimuli such as electroshock, strychnine and methionine sufoximine ${ }^{20-22}$ and to be influenced by agents that change the gabaergic function ${ }^{23}$.

It has been demonstrated that GABA system is involved in analgesia ${ }^{24}$. Other drugs corroborate the antinociceptive effect of GABA. The baclofen ( $\beta$-p-chlorophenyl-GABA), for instance, has been used in the treatment of trigeminal neuralgia ${ }^{25}$, atypical facial pain ${ }^{26}$, diabetic neuropathy ${ }^{27}$, central pain ${ }^{28}$ and experimental neuropathic pain ${ }^{29}$.

Vigabatrin, in our study, reverted significantly $(\mathrm{p}<0.05)$ the scratching behavior and the allodynia in the neuropathic rats, as well as the hyperalgesia, when present (Figs. 2 and 3). This effect involved the GABA system and not the opioid system, and this corroborated findings of other authors ${ }^{24}$. Santos ${ }^{29}$ has also reported similar results with baclofen, a gabaergic agent.

It has reported that vigabatrin may give, as side effects sedation and fatigue, and rarely hypothermia and diminished locomotion. This, however, did not happen in our animals so as to render then less active.

This possible analgesic effect of vigabatrin was corroborated by the results with valproic acid (also a gabaergic agent), carbamazepine and phenytoin, which similarly decreased significantly ( $\mathrm{p}<$ $0.05)$ the scratching behavior and increased significantly $(\mathrm{p}<0.05)$ the latency of paw withdrawal to 
thermal stimuli in the neuropathic animals. As reported by other workers, carbamazepine ${ }^{4,5}$, phenytoin and valproic acid have shown analgesic effect in different clinical conditions.

Both vigabatrin and valproic acid seem to induce an increase of GABA levels in brain as a consequence of inhibition of the enzyme GABA-T. Moreover, it also seems that these drugs may exert an effect on membrane $\mathrm{K}^{+}$canals $^{30}$.

Our results give a preliminary, and not yet described, indication of an analgesic effect of vigabatrin on experimental neuropathic pain. Further experiments will possibly define this hypothetical effect, which, if true, may become of importance for human clinical purposes.

\section{REFERENCES}

1. Withrington RH, Wynn Parry CB. The management of painful peripheral nerve disorders. J Hand Surg 1984;9B:24-28.

2. Davies HTO, Crombie IK, Londoale M, et al. Consensus and contention in the treatment of chronic nerve-damage pain. Pain 1991;47:191-196.

3. Blom S. Trigeminal neuralgia: its treatment with a new anticonvulsive drug (G32883). Lancet 1962;1:839-840.

4. Thompson T. Carbamazepine therapy in trigeminal neuralgia. Arch Neurol 1980;37: 699-703.

5. Rull JA, Quibrera R, Gonzales-Millan H, et al. Symptomatic treatment of peripheral diabetic neuropathy with carbamazepine (Tegretol): a double-blind, crossover trial. Diabetologia 1969;5:215-218.

6. Moura FEA. Estudo comportamental-farmacológico de ratos portadores de mononeuropatia ciática compressiva crônica: um modelo animal de dor neuropática crônica. Tese de Mestrado em Farmacologia. Faculdade de Medicina, Universidade Federal do Ceará. Fortaleza, 1995.

7. Chapman V, Suzuki R, Chamarette HLC, et al. Effects of systemic carbamazepine and gabapentin on spinal neuronal responses in spinal nerve ligated rats. Pain 1998; 75:261-272.

8. Shimoyama M, Shimoyama N, Inturrisi CE, et al. Gabapentin enhances the antinociceptive effects of spinal morphine in the rats tail flick test. Pain 1997;72:375-382.

9. Nakamura-Craig M, Follenfant RL. Effect of lamotrigine in the acute and chronic hyperalgesia in rats with streptozotocininduced diabetes. Pain 1995;63:33-37.

10. Zakrzewska JM, Chaudhry Z, Nurmikko TJ, et al. Lamotrigine (Lamictal) in refractory trigeminal neuralgia: results from a double-blind placebo controlled crossover trial. Pain 1997;73:223-230.

11. Grant SM, Heel RC. Vigabatrin: a review. Drugs 1991;41:889-926.

12. Bennett GJ, Xie YK. A peripheral mononeuropathy in rats that produces disorders of pain sensation like those seen in Man. Pain 1988;33:87-107.

13. Seltzer Z, Dubner R, Shir Y. A novel behavioral model of neuropathic pain disorders produced in rats by partial sciatic nerve injury. Pain 1990;43:205-218.

14. De Castro-Costa CM, De Sutter P, Gybels J, et al. Adjuvant induced arthritis in rats: a possible animal model of chronic pain. Pain 1981;10:173-185.

15. Kupers R, Nuytten D, De Castro-Costa CM, et al. A time course analysis of the spontaneous and evoked behaviour in a rat model of neuropathic pain. Pain 1992;50: 101-111.

16. Attal N, Jazat F, Kayser V et al. Further evidences for pain-related behaviours in a model of unilateral peripheral mononeuropathy. Pain 1990;41:235-251.

17. IASP, Committee for Research and Ethical Issues. Ethical standards for investigation of experimental pain in animal. Pain 1983;16:109-110.

18. Shorvon SD, Espir MLE, Steiner TJ, et al. Is there a place for placebo controlled trials of antiepiletic drug? Br Med J 1985;291:1328-1329.

19. Gram L, Larsson OM, Johnsen AH, et al. Effects of valproate, vigabatrin and aminooxyacetic acid on release of endogenous and exogenous GABA from cultured neurons. Epilepsy Res 1988;2:87-95.

20. Bernasconi R, Klein M, Martin P, et al. Gamma-vinyl-GABA: comparison of neurochemical and anticonvulsant effects in mice. J Neural Transm 1988;72:213-233.

21. Miller JW, McKeon AC, Ferrendelli JA. Functional anatomy of pentylenetetrazol and electroshock seizures in the rat brainstem. Ann Neurol 1987;22:615-621.

22. Toussi H, Schatz RA, Waszczak BL. Suppression of methionine sulfoximine seizures by intranigral Y-vinyl-GABA injection. Eur J Pharmacol 1987;137:261-264.

23. Liu Z, Seiler N, Marescaux C, et al. Potentiation of Y-VINYL-GABA (vigabatrin) effects by glycine. Eur J Pharmacol 1990;182:109-115.

24. DeFeudis FV. GABA-ergic analgesia: an overview. Drugs Today 1986;22:563-573.

25. Fromm GH, Terrence CF, Chattha AS. Treatment of face pain with Baclofen. Trans Am Neurol Assoc 1980;105:486-488.

26. Martins PI, Ferro JM. Atypical facial pain, ectasia of the basilar artery and baclofen: a case report. Headache 1989;29:581-583.

27. Anghinah R, Oliveira ASB, Gabbai AA. Effect of baclofen on pain in diabetic neuropathy. Muscle Nerve 1994;17:958-959.

28. Herman RM, D'Luzansky SC, Ippolifo R. Intrathecal baclofen suppresses central pain in patients with spinal lesions. Clin J Pain 1992;8:338-345.

29. Santos TJT. Analgesic effect of baclofen (beta-p-chlorofenil-GABA) in experimental neuropathic pain (Abstr). Arq Neuropsiquiatr 1996;54:712-713.

30. Porter RJ, Meldrum BS. Medicamentos antiepilépticos. In Katzunged BJ (ed). Farmacologia básica e clínica. 5Ed., Rio de Janeiro: Guanabara Koogan, 1992:248-261. 